\title{
Morphometry of Pterois volitans (Linnaeus, 1758) in the Veracruz Reef System in the Central Zone of the Gulf of Mexico
}

\author{
Ángel Roberto Reyes-Aguilar ${ }^{1}$, María del Refugio Castañeda-Chávez ${ }^{1 *}$, Jesús Montoya-Mendoza' ${ }^{1}$, Fabiola \\ Lango-Reynoso ${ }^{1}$, Rosa Elena Zamudio-Alemán ${ }^{1}$ and Julia Ramos-Miranda ${ }^{2}$
}

${ }^{1}$ TECNOLOGICO NACIONAL DE MEXICO/Instituto Tecnológico de Boca del Río, Mexico

${ }^{2}$ Instituto de Ecología, Universidad Autónoma de Campeche, México

Submission:December 12, 2017; Published: January 12, 2018

*Corresponding author: María del Refugio Castañeda-Chávez, Tecnológico Nacional de México/ Instituto Tecnológico de Boca del Río, Km 12,

Carretera Veracruz-Córdoba, C.P. 94290, Boca del Río, Ver. Mexico, Email: castanedaitboca@yahoo.com.mx

\section{Abstract}

The invasive species $P$. volitans (Linnaeus, 1758) has presented a significant geographic advance considering its original distribution, since the Indo-Pacific it has reached the west coast of the Atlantic, including mainly the Caribbean Sea and the Gulf of Mexico. In this geographic advance, protected areas are included and it is a reference species of impact on native species. Size, weight and distribution of the lionfish were evaluated in this study, in the Veracruz Reef System, National Park of the Gulf of Mexico. In the period from May to June 2016, 30 organisms were captured, their size and weight were recorded, comparing these meristic data with previous records in the area and other sites. An average height $( \pm \mathrm{SD})$ of $248.14 \pm 48.2 \mathrm{~mm}$ was reported in the analysis of the results, indicating a considerable increase in the size of the species in this study. It can be inferred that $P$. volitans possess a considerable ability to adapt and behave as opportunists, and being a natural predator has allowed them to reach these sizes.

Keywords: Invasive species; Pterois volitans; Total length; Veracruz; Mexico

\section{Introduction}

The invasive species $P$. volitans (Linnaeus, 1758) in marine ecosystems is of international importance, since it represents competition or predation of native species, mainly in the reef areas of the Gulf of Mexico and the Caribbean Sea. Due to this situation, studies have been initiated to know the population aspects of this invasive species on the west coast of the Atlantic [1]. According to scientific reports, the first record of $P$. volitans occurred in 2009 in the Marine Protected Areas of the SouthWest Reef Corridor of the Gulf of Mexico [2]. Subsequently, in 2012, its presence was reported in the Lobos-Tuxpan Reef System (SALT) [3] and in the Veracruz Reef System National Park (PNSAV) [4]. In this study, size and weight of $P$. volitans from the PNSAV reefs of the central zone of the Gulf of Mexico were analyzed, comparing the length of the lionfish with previous records of the area.

\section{Materials and Methods}

Between the months of May and June 2016, 30 specimens of $P$. volitans were collected, using harpoon and basic fishing equipment, in the Veracruz Reef System National Park (PNSAV). This system is located on the central coast of the state of Veracruz $\left(19^{\circ} 16.106^{\prime} \mathrm{N}, 096^{\circ} 12.133^{\prime} \mathrm{O}\right.$ and $\left.19^{\circ} 0.520^{\prime} \mathrm{N}, 095^{\circ} 45.933^{\prime} \mathrm{O}\right)$. The Protected Natural Area of the PNSAV includes 28 reefs, [5-
8]. The amount of specimens collected specifically in 8 out of 28 reefs were: from the northern part of the PNSAV: Gallega (1) and Galleguilla (7); from the central part: Isla Verde (6) and La Palma (4); and from the southern part: El Giote (1), La Blanca (2), Sargazo (3) and Santiaguillo (6). The collected organisms were transported in plastic containers with ice to the facilities of the Laboratory of Applied Aquaculture Research (LIAA) of the Technological Institute of Boca del Río (ITBOCA), each specimen was taken data of total length ( $\mathrm{mm}$ ) and weight (grams) identifying them following the criteria of Schultz [9].

\section{Results and Discussion}

The recorded size of the 30 specimens was 157 to 397 (248.14 \pm 48.19$) \mathrm{mm}$ and weight of 48 to $1063(279.17 \pm 221.76) \mathrm{g}$. The number of specimens according to the size distribution was of: $150-200 \mathrm{~mm}$ (1), 201-250mm (19), 251-300mm (6), 301$350 \mathrm{~mm} \mathrm{(3)}$ and $351-400 \mathrm{~mm}(1)$, where the highest frequency of weight was in the range of 100 to $200 \mathrm{~g}(17)$. The largest fish presented $397 \mathrm{~mm}$ in length with a weight of $1063 \mathrm{~g}$. The record of lionfish in the northern, central and southern reefs of the PNSAV indicates that this species is already distributed throughout the marine park, and that the largest sizes are found in the deepest reefs or farthest from the line of coast. On the other hand, it is 
relevant to point out that in the regional context, the size of the lionfish is increasing for coasts of Veracruz with $[3,4,10,11]$. Meanwhile, the size obtained in our data $(248.14 \pm 48.19)$ is similar to those recorded in Mexico in the Gulf of Mexico and Caribbean littoral. As they are: Tamaulipas: $157 \mathrm{~mm} \mathrm{[12];}$ Veracruz: $185 \mathrm{~mm}$ [4], 92-405mm [11], 90-397mm [10]; Tabasco, 245-250mm [13]; Campeche, 365mm [14]; Yucatan, 137mm [2], 90-274mm [15], 390mm [16], 98-358mm [17]; Quintana Roo, 25-365mm [18], 150-390mm [19]. Comparatively, the length of the lionfish has records of $390 \mathrm{~mm}$ [16], 390mm [19], 397mm [10] and a maximum of $405 \mathrm{~mm}$ [11] next similar to the other latitudes as in the Bahamas with $420 \mathrm{~mm}$ [20]; USA, North Carolina with $450 \mathrm{~mm}$ [21], Florida with $474 \mathrm{~mm}$ [16].

The above data allow us to point out that over time, larger organisms are being collected, given the invasion by $P$. volitans in the Veracruz Reef System National Park. In addition, the records in other reef systems in which $P$. volitans has been established, highlights the capacity of its success as an invasive alien species. The analysis in the distribution of this type of species provides information on the potential impacts that this species can cause, by identifying an increase in its size or weight. As a result of this phenomenon, another impact on the ecosystem can be generated, such as: the alteration in the dynamics of endemic species, which can be displaced by competition or potential prey to an organism that is opportunistic, predatory and easy to adapt, which has no physical limitations or predators, therefore represents a successful establishment in the Atlantic Ocean, Caribbean Sea, Gulf of Mexico and recently, on the coasts of Brazil (250mm, Ferreira et al. 2015). It is necessary to continue with research studies on their invasion to the coasts of regions not officially reported, scientifically strengthen their biological and ecological characteristics, as well as the negative and positive impacts on ecosystems.

\section{Acknowledgement}

The environmental biotechnology research line in marine coastal ecosystems. To the National Technologist of México / ITBOCA.

\section{Conflict of Interest}

The authors declare no conflict of interest.

\section{References}

1. Chagaris D, Binion-RS, Bogdanoff A, Dahl K, Granneman J, et al (2017) An ecosystem-Based Approach to Evaluating Impacts and Management of Invasive Lionfish. Fisheries 42(8): 421-431.

2. Aguilar-PA, Tuz-SA (2010) Non-native, invasive red lionfish (Pterois volitans [Linnaeus, 1758]: Scorpaenidae), is first recorded in the southern Gulf of Mexico, off the northern Yucatan Peninsula, Mexico. Aquatic Invasions 5(Suppl 1): S9-S12.

3. González-G, De la Cruz, Francisco SP, Domínguez JJ (2012) Lista de peces de Tuxpan, Veracruz, México. Revista Científica UDO Agrícola 12(3): 675-689.

4. Santander-MJ, López-HI, Aguilar-PA, Tuz-SA (2012) First record of the red lionfish (Pterois volitans [Linnaeus, 1758]) off the coast of Veracruz, Mexico. Bioinvasions Records 1(2): 121-124.
5. Diario Oficial de la Federación (DOF) (2017) Programa de Manejo del Área Natural Protegida. Parque Nacional Sistema Arrecifal Veracruzano. Estados Unidos Mexicanos.- Secretaría de Medio Ambiente y Recursos Naturales. Publicado 22 de mayo de 2017.

6. Jiménez-BML, Cruz-RS, Lozano-AMA, Rodríguez-QG (2014) Problemática ambiental y socioeconómica del Parque Nacional Sistema Arrecifal Veracruzano. Investigación y Ciencia 22(60): 58-64.

7. Gold-BG, Rubio-PJ, Montero-MJ, Ramírez-MN, Echeverria-GA, et al. (2017) Pollutants and biomarker responses in two reef fish species (Haemulon aurolineatum and Ocyurus chrysurus) in the Southern Gulf of Mexico. Marine Pollution Bulletin 116(1-2): 249-257.

8. Liaño-CF, Ramírez-MJI, Salas-MD, Riveron-EML, Rangel-AM, RoldánUAA (2017) Sediment Transport Monitoring in the Port of Veracruz Expansion Project. International Journal of Environmental, Chemical, Ecological, Geological and Geophysical Engineering 11(3): 189-194.

9. Schultz ET (1986) Pterois volitans and Pterois miles: two valid species. Copeia 1986(3): 686-690.

10. Montoya-MJ, Camarena-LT, Castañeda-CMR, Lango-RF (2017) Helminth Parasites of Red Lionfish, Pterois volitans from the Veracruz Coral Reef System, Mexico, Southern Gulf of Mexico. Journal of Agricultural Science 9(11): 30-33.

11. Acevedo-LD (2015) Ecología alimentaria del pez león (Pterois spp.) en el Sistema Arrecifal Veracruzano, Suroeste del Golfo de México. Tesis de licenciatura en Biología, Tecnológico Nacional de México/Instituto Tecnológico de Boca de Río p. 40.

12. Arellano-MLU, Mora-OA, Zamora-TC, De la Rosa-ME (2017) First report of the invasive red lionfish Pterois volitans (Linnaeus, 1758) (Scorpaenidae) on the coast of Tamaulipas, Mexico. BioInvasions Records 6(3): 255-258.

13. Wakida-KAT, Amador del Ángel LE (2015) First record of the red lionfish, Pterois volitans, on the coast of Tabasco, Mexico. Hidrobiológica 25(2): 307-309.

14. Sosa-LA, Juárez-CP, Del Río-RR, Ayala-PLA, Romero-HeCU, Gómez-SMI (2017) First record of invasive red lionfish (Pterois volitans [Linnaeus, 1758]: Scorpaenidae) in waters of a natural protected area from Campeche, México, E-BIOS 1(13): 10-15.

15. Aguilar-PA, Tuz-SA, Perera-CL, López-GMJ, González-TX, CarrilloFE (2012) Lionfish invasion off the northern Coast of the Yucatan Peninsula, Mexico, Southern Gulf of Mexico: what do we know? $64^{\text {th }}$ Gulf and Caribbean Fisheries Institute 64: 34-38.

16. Aguilar-PA, Perera-CL, Quijano-PL (2013) Record body size for the Red Lionfish, Pterois volitans (Scorpaeniformes), in the Southern Gulf of Mexico. Gulf and Caribbean Research 25(1): 121-123.

17. Aguilar-PA, Quijano-PL (2016) Relations between fish length to weight, and otolith length and weight, of the Lionfish Pterois volitans in the Parque Nacional Arrecife Alacranes, southern Gulf of Mexico. Revista de Biología Marina y Oceanografía 51(2): 469-474.

18. Sabido-IMM, Medina-QA, De Jesús-NA, Gómez-PJM, García-RMC (2016) La Estructura de tallas como evidencia del establecimiento de Pterois volitans (Scorpaeniformes: Scorpaenidae) en el sur del Caribe mexicano. Revista de Biología Tropical 64(1): 369-378.

19. Rodríguez-SMA, Ávila E, Caballero-VA J, Guevara-CE, Amador-del ÁLE, et al. (2015) Primer registro parasitológico del pez león Pterois volitans (Pisces: Scorpaenidae) en costas de Quintana Roo, México. V Congreso sobre Manejo de Ecosistemas y Biodiversidad, At La Habana, Cuba 1: 1-10.

20. Morris JA, Akins JL (2009) Feeding ecology of invasive lionfish (Pterois volitans) in the Bahamian archipelago. Environmental Biology of Fishes 86: 389-398.

21. Whitfield PE, Hare JA, David AW, Harter SL, Muñoz RC, et al. (2007) Abundance estimates of the Indo-Pacific lionfish Pterois volitans/miles 
complex in the Western North Atlantic. Biological Invasions 9(1): 53-

64.

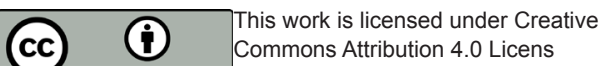

Commons Attribution 4.0 Licens

BY DOI: 10.19080/OFOAJ.2018.05.555673

Your next submission with Juniper Publishers will reach you the below assets

- Quality Editorial service

- Swift Peer Review

- Reprints availability

- E-prints Service

- Manuscript Podcast for convenient understanding

- Global attainment for your research

- Manuscript accessibility in different formats

(Pdf, E-pub, Full Text, Audio)

- Unceasing customer service

Track the below URL for one-step submission https://juniperpublishers.com/online-submission.php 